\title{
Dimensions and allometry of testes, epididymides and spermatozoa in the domestic dog (Canis familiaris)
}

\author{
P. F. Woodall* and I. P. Johnstone $†$ \\ Department of Veterinary Anatomy, University of Queensland, St Lucia, Queensland 4067, \\ Australia
}

\begin{abstract}
Summary. Dimensions of the testes, epididymides and spermatozoa were measured from a sample of 104, mainly cross-bred, domestic dogs ranging in body mass from 5 to $48 \mathrm{~kg}$. Allometric analyses in relation to body mass indicated isometric changes in testicular mass but epididymal mass and the mass of the cauda epididymidis and sperm numbers in the cauda showed significant positive allometry. Total sperm length, seminiferous tubule diameter and the relative proportion of tissues in the testis showed no significant correlation with body mass, but sperm principal piece length showed a low correlation with body mass. We suggest that the positive allometry of epididymal mass and sperm numbers is related to promiscuous mating and sperm competition in stray dogs.
\end{abstract}

Keywords: testis; epididymis; spermatozoa; dog; allometry

\section{Introduction}

Allometric analyses of reproductive and other organ systems provide mathematical descriptions of relative changes in the size of these structures with respect to body size. Previous allometric analyses of male reproductive organs have been concerned with the interspecific variation of spermatozoa (Cummins \& Woodall, 1985) and testis mass (Harcourt et al., 1981; Kenagy \& Trombulak, 1986) but there are few studies on intraspecific variation in male reproductive characteristics: it is important to distinguish between variation in the size of adult males (as investigated here) and variation during the growth and development of the individuals, ontogenetic allometry (Gould, 1966). Islam \& Land (1977) described seasonal changes in testis size and sperm output of different breeds of rams and found that breed differences in testis diameter were much smaller in adults than among juveniles. Short (1984) reported variation in human testis size in different races and commented on the absence of information concerning the anatomical reasons for this variation.

This study attempts to provide more information on intraspecific variation of male reproductive organs and spermatozoa using the domestic dog as a model. The diversity of breeds of domestic dog present a 35-fold range in body mass (Kirkwood, 1985). Previous studies of canids have investigated allometric variation in various organs, and in physiological and behavioural measures (Bekoff et al., 1981; Kirkwood, 1985) but there have been no allometric investigations of male reproductive organs.

\section{Materials and Methods}

Male dogs were obtained less than $1 \mathrm{~h}$ after being killed at the R.S.P.C.A. animal refuge in Brisbane between May and October 1984 and April and May 1987. Only 27\% were recognized as a specific breed and the remainder were

*Present address: Department of Anatomy, University of Queensland, St Lucia, Queensland 4067, Australia. $\dagger$ Present address: Faculty of Veterinary Science, University of Queensland, St Lucia, Queensland 4067, Australia. 
considered to be cross-breeds. Dogs under 6 months of age, identified by the presence of deciduous canines (Evans $\&$ Christensen, 1979), were excluded from the sample. The others were then weighed on a spring scale, accurate to $0 \cdot 2 \mathrm{~kg}$, and both testes and epididymides were removed. The epididymides were carefully dissected from the testes and they were weighed separately on a top-pan balance, accurate to $0.01 \mathrm{~g}$. Individuals that had no spermatozoa in histological sections of the testis or in sperm smears from the cauda epididymidis (see below) were excluded from subsequent analyses.

Histology. A small segment from the equatorial region of one testis was removed and fixed in Bouin's solution. This was later processed using standard histological procedures, sectioned at $7 \mu \mathrm{m}$ and stained with haematoxylin and eosin. Seminiferous tubule diameter was measured using a projection microscope and the mean diameter of 10 round tubules was calculated. The relative areas occupied by germinal tissue; Leydig cells; and blood vessels + connective tissue were estimated using a projection microscope and recording the tissue under 100 points of a standard stereological grid (Elias \& Hyde, 1980). The total area of seminiferous tubules (i.e. germinal epithelium + lumen) was also estimated.

Sperm dimensions. A sperm smear was made from spermatozoa expressed from one cauda epididymidis and stained with aqueous nigrosin-eosin (Campbell et al., 1956). Sperm dimensions (Table 1) were later measured from this slide using an oil immersion objective $(\times 100)$ on a microscope coupled to a closed-circuit TV. After initial calibration using a stage micrometer, sperm dimensions were measured directly off the TV screen. This provided images of high magnification and high resolution, allowing measurements accurate to $0.3 \mu \mathrm{m}$ and enabling the end piece to be included in measurements of total sperm length and principal piece length.

Sperm numbers in the cauda epididymidis. On the other epididymis, the cauda, readily identified by the presence of small tubules visible at the surface, was cut off, diced with a scalpel and then ground in a tissue grinder. The macerated tissue was placed in a glass tube and all instruments and glassware were rinsed three times with a diluent $(0.9 \%$, $\mathrm{NaCl}+0.5 \%$ Triton X-100) and the suspension was made up to $20 \mathrm{ml}$. This was placed in an ultrasonic homogenizer for 3-6 min, then further diluted before the sperm heads were counted in a Fuchs Rosenthal haemocytometer. The mean count from 6 chambers $(4 \times 4)$ was used to calculate total sperm numbers in the sample.

Statistical analysis. Means, standard errors of the mean and co-efficients of variation were calculated for each variable using standard procedures (Sokal \& Rohlf, 1981). When smaller sub-samples of the total sample were used for some measures (e.g. seminiferous tubule diameter, sperm counts) care was taken to ensure that the complete range of body mass was still represented. When two variables were compared with each other, a product-moment correlation was calculated as an initial step. Further allometric analysis was only undertaken when there was a significant correlation $(P<0.05)$.

Allometric analyses were made using the power function (Gould, 1966):

$$
y=\mathrm{b} x^{a}
$$

where $x$ is the independent variable (usually body mass); $y$ is the dependent variable; $b$ is a constant and $\alpha$ is the allometric coefficient. Logarithmic transformation of this function gives:

$$
\log y=\alpha \log x+\log b
$$

which enables the allometric co-efficient, $\alpha$, to be estimated as the gradient of the straight line fitted to the log $y$ versus $\log x$ plot.

Although linear regression techniques have frequently been used to fit the straight line to this plot, this is statistically invalid (Gould, 1966) and gives consistently low values of $\alpha$ (Seim \& Saether, 1983). In this work, therefore, $\alpha$ was estimated by fitting a line using major-axis analysis and reduced major-axis analysis. Major-axis analysis was used when the error variances of $x$ and $y$ were not significantly different and reduced major-axis analysis was used when the variances were different (Seim \& Saether, 1983).

When an organ changes as a constant proportion of body mass, $\alpha=1$ (isometry), but when an organ increases more rapidly than body size, $\alpha=>1$ (positive allometry). To test the departure of $\alpha$ from isometry, $95 \%$ and $99 \%$ confidence limits for a were calculated using the methods described in Sokal \& Rohlf (1981). If the lower confidence limits were greater than 1 , then $\alpha$ was considered to show significant positive allometry.

\section{Results}

\section{Dimensions of body mass, testes, epididymides and spermatozoa}

The dogs used in this study showed almost a 10 -fold range in body mass with a slightly smaller range for testicular mass and a larger range for epididymal mass (Table 1). The mass of the cauda epididymidis and the numbers of spermatozoa in the cauda epididymidis showed an even greater range, over 20 -fold (Table 1 ). In contrast, the seminiferous tubule diameters and dimensions of the spermatozoa showed a much smaller range of size. These differences are also reflected in the differing magnitude of the co-efficient of variation (Table 1). It is clear from this that some variables vary in a 
Table 1. Measurements of body mass, testes, epididymides and spermatozoa in dogs

\begin{tabular}{|c|c|c|c|c|c|}
\hline Variable & $\begin{array}{l}\text { Sample } \\
\text { size }\end{array}$ & Mean & Range & $\begin{array}{l}\text { s.e. of } \\
\text { mean }\end{array}$ & $\begin{array}{l}\text { Coefficient } \\
\text { of variation }\end{array}$ \\
\hline Body mass (kg) & 104 & $21 \cdot 62$ & $5 \cdot 4-48 \cdot 1$ & 0.80 & $37 \cdot 5$ \\
\hline Combined testis mass (g) & 104 & 27.66 & $8 \cdot 2-50 \cdot 7$ & 1.00 & $36 \cdot 8$ \\
\hline Epididymis mass (g)* & 93 & $3 \cdot 13$ & $0.86-10.42$ & $0 \cdot 16$ & $48 \cdot 6$ \\
\hline Cauda epididymidis mass (g)* & 93 & 0.83 & $0 \cdot 16-3 \cdot 37$ & 0.051 & $59 \cdot 1$ \\
\hline $\begin{array}{l}\text { Caput }+ \text { corpus } \\
\text { epididymidis mass }(\mathrm{g})^{*}\end{array}$ & 93 & $2 \cdot 30$ & $0 \cdot 70-7 \cdot 18$ & $0 \cdot 11$ & $46 \cdot 7$ \\
\hline $\begin{array}{l}\text { Sperm numbers in the } \\
\text { paired cauda epididymidis }\left(\times 10^{-6}\right)\end{array}$ & 55 & 2138 & $227-7144$ & 180 & $62 \cdot 6$ \\
\hline Seminiferous tubule diam. $(\mu \mathrm{m})$ & 55 & 186 & $143-245$ & $2 \cdot 87$ & $11 \cdot 5$ \\
\hline $\begin{array}{l}\text { Spermatozoa }(\mu \mathrm{m}) \\
\text { Total length } \\
\text { Head length } \\
\text { Head width } \\
\text { Midpiece length } \\
\text { Principal piece length }\end{array}$ & $\begin{array}{l}69 \\
69 \\
69 \\
69 \\
69\end{array}$ & $\begin{array}{r}61 \cdot 4 \\
6 \cdot 1 \\
3 \cdot 8 \\
10 \cdot 1 \\
45 \cdot 2\end{array}$ & $\begin{array}{r}57 \cdot 5-66 \cdot 1 \\
5 \cdot 5-7 \cdot 4 \\
3 \cdot 5-4 \cdot 3 \\
8 \cdot 0-11 \cdot 7 \\
41 \cdot 8-50 \cdot 0\end{array}$ & $\begin{array}{l}0.244 \\
0.037 \\
0.023 \\
0.074 \\
0.214\end{array}$ & $\begin{array}{l}3 \cdot 29 \\
5.05 \\
5 \cdot 12 \\
6.08 \\
3.92\end{array}$ \\
\hline
\end{tabular}

*One side only.

Table 2. The relative proportion of tissues in the testes of the domestic dog

\begin{tabular}{lcrrcc}
\hline Variable & $\begin{array}{c}\text { Sample } \\
\text { size }\end{array}$ & Mean & Range & $\begin{array}{r}\text { s.e. of } \\
\text { mean }\end{array}$ & $\begin{array}{c}\text { Coefficient } \\
\text { of variation }\end{array}$ \\
\hline $\begin{array}{l}\text { \% Seminiferous tubule } \\
\text { (germinal epithelium + lumen) }\end{array}$ & 55 & $84 \cdot 8$ & $74-92$ & 0.58 & $5 \cdot 0$ \\
$\begin{array}{l}\text { \% Leydig cells } \\
\begin{array}{l}\text { \% connective tissue }+ \\
\text { blood vessels, etc. }\end{array}\end{array}$ & 55 & 6.4 & $2-11$ & 0.28 & 32.0 \\
\hline
\end{tabular}

similar (or even greater) extent to body size while others show very little variation. This is considered in more detail below.

\section{Relative proportions of tissues in the testes}

The relative proportions of various tissues in the testes are presented in Table 2 . The proportion of germinal epithelium showed little variation, reflecting the comparatively low variation found in seminiferous tubule diameter (Table 1). The proportions of 'Leydig cells' and 'connective tissue + blood vessels, etc.' both showed fairly high variation.

When allometric analyses were performed, no significant correlations were found between any tissue proportion and testis mass $(P>0.05)$. Therefore the variation observed in the relative proportion of various tissues of the testis cannot be accounted for by changes in testis size and may be the result of differences in sexual maturity (post-pubertal) and fixation artefacts. 
Table 3. Relationships between reproductive variables of male domestic dogs

\begin{tabular}{|c|c|c|c|}
\hline Variable & $\begin{array}{l}\text { Sample } \\
\text { size }\end{array}$ & $\begin{array}{l}\text { Correlation } \\
\text { coefficient }\end{array}$ & $\begin{array}{c}\text { Allometry coefficient } \\
\left(^{*}=95 \% \text { confidence limits }\right. \\
\left.*^{*}=99 \% \text { confidence limits }\right)\end{array}$ \\
\hline $\begin{array}{l}\text { Testicular mass } v s \\
\text { body mass }\end{array}$ & 104 & 0.8376 & $\begin{array}{c}1 \cdot 057^{\mathrm{M}} \\
(0 \cdot 89-1 \cdot 25)^{* *}\end{array}$ \\
\hline $\begin{array}{l}\text { Total epididymal mass } v s \\
\text { body mass }\end{array}$ & 93 & 0.7509 & $\begin{array}{c}1 \cdot 207^{\mathrm{R}} \\
(1 \cdot 04-1 \cdot 37)^{*} \\
(0.99-1 \cdot 42)^{* *}\end{array}$ \\
\hline $\begin{array}{l}\text { Total epididymal mass } v s \\
\text { testicular mass }\end{array}$ & 93 & 0.7940 & $\begin{array}{c}1 \cdot 165^{\mathrm{M}} \\
(0 \cdot 94-1 \cdot 45)^{* *}\end{array}$ \\
\hline $\begin{array}{l}\text { Cauda epididymidis mass } v s \\
\text { body mass }\end{array}$ & 93 & 0.6505 & $\begin{array}{c}1 \cdot 507^{\mathrm{R}} \\
(1 \cdot 19-1 \cdot 82)^{* *}\end{array}$ \\
\hline $\begin{array}{l}\text { Cauda epididymidis mass } v s \\
\text { testicular mass }\end{array}$ & 93 & 0.7006 & $\begin{array}{c}1.410^{\mathrm{R}} \\
(1 \cdot 13-1 \cdot 69)^{* *}\end{array}$ \\
\hline $\begin{array}{l}\text { Cauda epididymidis mass vs } \\
\text { epididymal mass }\end{array}$ & 93 & 0.9348 & $\begin{array}{c}1 \cdot 248^{\mathrm{R}} \\
(1 \cdot 13-1 \cdot 37)^{* *}\end{array}$ \\
\hline $\begin{array}{l}\text { Sperm numbers in cauda vs } \\
\text { body mass }\end{array}$ & 55 & 0.5202 & $\begin{array}{c}1 \cdot 701^{\mathrm{R}} \\
(1 \cdot 17-2 \cdot 33)^{* *}\end{array}$ \\
\hline $\begin{array}{l}\text { Sperm numbers in cauda } v s \\
\text { testicular mass }\end{array}$ & 55 & 0.6211 & $\begin{array}{c}1 \cdot 687^{\mathrm{R}} \\
(1 \cdot 20-2 \cdot 17)^{* *}\end{array}$ \\
\hline $\begin{array}{l}\text { Sperm numbers in cauda } v s \\
\text { epididymal mass }\end{array}$ & 50 & 0.6553 & $\begin{array}{c}1 \cdot 697^{\mathrm{R}} \\
(1 \cdot 20-2 \cdot 19)^{* *}\end{array}$ \\
\hline $\begin{array}{l}\text { Sperm numbers in cauda } v s \\
\text { cauda epididymidis mass }\end{array}$ & 50 & 0.6431 & $\begin{array}{c}1.587^{\mathrm{M}} \\
(1.03-2 \cdot 71)^{* *}\end{array}$ \\
\hline
\end{tabular}

$P<0.001$ for all correlation coefficients.

All variables were transformed to logs. The preferred allometric coefficient from major-axis analysis (M) or reduced major-axis analysis (R) is indicated by superscript (see 'Methods' for details).

\section{Allometric relationships of testes, epididymides and sperm numbers}

The change in testicular mass with body mass showed an isometric relationship, both increased in similar proportion and the $95 \%$ and $99 \%$ confidence limits of $\alpha$, the allometry co-efficient, included 1.0 (Table 3 ).

Total epididymal mass showed positive allometry with body mass ( $\alpha=>1$ at the $95 \%$ level) but was isometric with testis mass (Table 3 ).

Changes in the mass of the cauda epididymidis with body mass, testicular mass and total epididymal mass all showed significant positive allometry, that is the cauda epididymidis mass increased more rapidly than body mass, with the $99 \%$ confidence limits of $\alpha$ all being greater than 1.0 (Table 3). Sperm numbers in the cauda epididymidis also showed positive allometry with body mass, testicular mass, epididymal mass and mass of the cauda epididymidis (Table 3 ).

Seminiferous tubule diameter $(n=55)$ was not significantly correlated with body mass $(r=$ $0 \cdot 0524)$, testicular mass $(r=0 \cdot 1051)$ or total sperm length $(r=0 \cdot 2037)$ and no allometric analyses were undertaken.

\section{Allometric analyses of sperm lengths}

Total sperm length $(n=69)$ was not significantly correlated with body mass $(r=0 \cdot 1479)$, testicular mass $(r=0 \cdot 1051)$ or seminiferous tubule diameter (see above). Sperm head length was not correlated with total sperm length but the mid-piece and principal piece length were significantly correlated to total length, both with positive allometry (Table 4). The high correlation coefficient 
Table 4. Allometry of spermatozoa of domestic dogs

\begin{tabular}{|c|c|c|c|}
\hline Variable & $\begin{array}{l}\text { Sample } \\
\text { size }\end{array}$ & $\begin{array}{l}\text { Correlation } \\
\text { coefficient }\end{array}$ & $\begin{array}{l}\text { Allometry coefficient } \\
(99 \% \text { confidence limits) }\end{array}$ \\
\hline $\begin{array}{l}\text { Sperm head length } v s \\
\text { total sperm length }\end{array}$ & 69 & $0 \cdot 1698$ & \\
\hline $\begin{array}{l}\text { Sperm midpiece length } v s \\
\text { total sperm length }\end{array}$ & 69 & $0 \cdot 5414^{* * *}$ & $\begin{array}{c}1 \cdot 906^{\mathrm{R}} \\
(1 \cdot 39-2 \cdot 43)\end{array}$ \\
\hline $\begin{array}{l}\text { Principal piece length } v s \\
\text { total sperm length }\end{array}$ & 69 & $0.9298^{* * *}$ & $\begin{array}{c}1 \cdot 198^{\mathrm{M}} \\
(1 \cdot 06-1 \cdot 36)\end{array}$ \\
\hline $\begin{array}{l}\text { Sperm midpiece length } v s \\
\text { body mass }\end{array}$ & 69 & $-0.2194 \dagger$ & \\
\hline $\begin{array}{l}\text { Principal piece length } v s \\
\text { body mass }\end{array}$ & 69 & $0 \cdot 2830^{*}$ & $\begin{array}{c}0 \cdot 118^{R} \\
(0 \cdot 08-0 \cdot 15)\end{array}$ \\
\hline
\end{tabular}

$\dagger P<0 \cdot 10 ;{ }^{*} P<0.05 ;{ }^{* * *} P<0.001$.

All variables were transformed to logs. The preferred allometric coefficient from majoraxis analysis $(M)$ or reduced major-axis analysis $(R)$ is indicated by superscript (see 'Methods' for details).

indicates that most of the variation in total sperm length is accounted for by variation in principal piece length and not by the other components. Head length showed no significant correlation with body mass $(r=-0 \cdot 1694, n=69)$ but principal piece length showed a significant correlation with body mass and midpiece length showed a negative correlation with body mass which was nearly significant at the $5 \%$ level (Table 4).

\section{Discussion}

Wildt et al. (1982) have shown that inbreeding can have detrimental effects on reproductive parameters in dogs, including reduction in ejaculate quality and testicular volume. The high proportion of cross-breeds $(73 \%)$ in this sample from the animal refuge suggests that this is unlikely to be a consideration in the present work. It may also suggest that most of these dogs were freeranging, defined as "any owned or unowned animal that is not under immediate human supervision and on (or having access to) public property" (Beck, 1973). This has important implications for the type of mating system used by these dogs (see below).

Kenagy \& Trombulak (1986) investigated the relation between testis mass and body size in 133 species of mammals representing 13 orders and found significant negative allometry $(\alpha=0.72)$. They used linear regression analysis to fit a straight line to their data but re-analysing their data using major-axis analysis or reduced major-axis analysis gave similar results $(\alpha=0.76$ and 0.77 respectively, both significantly lower than isometry, $P<0 \cdot 01$ ). Kenagy \& Trombulak (1986) also analysed intraspecific variation of testis size in three species of rodents and found wide variation in relative testis size, concluding that "variation in body mass and testis mass is probably largely independent". These results contrast with the isometric relation of testis mass to body mass and the positive allometry of total epididymal mass and mass of the cauda epididymidis to body mass found in this study.

Seasonal and post-pubertal changes in testis size are largely associated with changes in sperm production (Setchell, 1978) but in this sample of domestic dogs the variation of testis size was not correlated with changes in the proportion of any tissue component and the proportion of seminiferous tubules (germinal epithelium + lumen) remained remarkably constant over a wide range of testis size.

Parker (1984) indicates that, when there are two (or more) ejaculates in competition, relative sperm numbers may be the major factor that determines the probability of successful fertilization. 
Relatively large testes are found in primates (Harcourt et al., 1981; Harvey \& Harcourt, 1984) and other mammals (Kenagy \& Trombulak, 1986) which have promiscuous mating systems, with more than one breeding male and multiple inseminations leading to sperm competition in the female tract, compared with similar species that have a non-promiscuous system. Kenagy \& Trombulak (1986) found that carnivores ( 7 species, not including Canis), had small testes with a mean relative testis size (observed testis mass/predicted testis mass from the allometric equation for all mammals) of 0.54 . They suggested that the reason for this small relative size of testes was that carnivores are generally monogamous and that species with single-male mating systems have smaller testes than those with multiple-male mating systems. Following Kenagy \& Trombulak's (1986) calculations, our data indicate that the domestic dog also has relatively small testes, with a relative size of 0.58 .

Free-ranging domestic dogs no longer retain the monogamous mating system of most wild canids (Kleiman, 1977) but have a promiscuous mating system in which the female exercises some degree of choice of mate (Daniels, 1983) although some instances of 'rape' by large, aggressive dogs have been reported (Ghosh et al., 1984). These observations of multiple inseminations together with evidence that spermatozoa can survive in the female tract of bitches for up to 11 days (Doak et al., 1967) indicate that sperm competition is frequent in free-ranging domestic dogs.

While the testicular size of domestic dogs is relatively small, similar to that found in wild canids, their sperm stores (mass of the cauda epididymidis, sperm numbers in the cauda epididymidis) show positive allometry, with larger increases than expected for increases in body or testicular mass. This may be a response to increased sperm competition in domestic dogs resulting from their promiscuous breeding system. It would be very interesting to obtain comparative information on the size of sperm stores in wild canids which are monogamous.

Cummins \& Woodall (1985) showed that there was a significant negative correlation between total sperm length and body mass in 284 species of mammals $(r=-0.445, P<0.001)$ and when these data were re-analysed a significant negative correlation was also found between midpiece length and body mass $(r=-0.377, P<0.01)$. In domestic dogs there was a significant positive correlation between principal piece length and body mass and a non-significant negative correlation between midpiece length and body mass (Table 4) and this resulted in no significant correlation between total sperm length and body mass. The significant correlation between principal piece length and body mass in domestic dogs was low, accounting for only $8 \%$ of the total variation in sperm length, and is probably of little consequence. Clearly, intraspecific analysis of sperm morphology in dogs shows no strong relationship between sperm length and body mass similar to that found in the interspecific analysis for all mammals.

Some of the variation in sperm length in dogs may be due to breed differences since the length of the midpiece is known to be highly heritable in strains of mice and occurs without similar changes to the length of the principal piece (Woolley \& Beatty, 1967; Beatty, 1970; Woolley, 1971). This aspect requires further investigation in the domestic dog but, compared to the large differences in body mass produced by selective breeding, sperm dimensions were comparatively uniform in this sample of largely cross-bred dogs.

We thank the Queensland R.S.P.C.A. for providing access to the animals; Mr P. C. Addison, MrT. R. Burgess, Mr G. C. Godbold and Mr I. G. Shannon for technical assistance; the Department of Zoology, University of Queensland, for use of the TV/microscope equipment; and Dr J. M. Cummins and Professor T. D. Glover for useful comments on a draft of this paper.

\section{References}

Beatty, R.A. (1970) The genetics of the mammalian gamete. Biol. Rev. 45, 73-119.

Beck, A. (1973) The Ecology of Stray Dogs: A Study of Free-ranging Urban Animals. York Press, Baltimore.
Bekoff, M., Diamond, J. \& Mitton, J.B. (1981) Lifehistory patterns and sociality in canids: body size, reproduction and behavior. Oecologia (Berl.) 50, 386-390. 
Campbell, R.C., Dott, H.M. \& Glover, T.D. (1956) Nigrosin-eosin as a stain for differentiating live and dead spermatozoa. J. agric. Sci., Camb. 48, 1-8.

Cummins, J.M. \& Woodall, P.F. (1985) On mammalian sperm dimensions. J. Reprod. Fert. 75, 153-175.

Daniels, T.J. (1983) The social organization of freeranging urban dogs. II Estrous groups and the mating system. Appl. Anim. Ethol. 10, 365-373.

Doak, R.L., Hall, A. \& Dale, H.E. (1967) Longevity of spermatozoa in the reproductive tract of the bitch. $J$. Reprod. Fert. 13, 51-58.

Elias, H. \& Hyde, D.M. (1980) An elementary introduction to stereology (quantitative microscopy). Am. J. Anat. 159, 411-446.

Evans, H.E. \& Christensen, G.C. (1979) Miller's Anatomy of the Dog, 2nd edn. W.B. Saunders, Philadelphia.

Ghosh, B., Choudhuri, D.K. \& Pal, B. (1984) Some aspects of the sexual behaviour of stray dogs Canis familiaris. Appl. Anim. Behav. Sci. 13, 113-127.

Gould, S.J. (1966) Allometry and size in ontogeny and phylogeny. Biol. Rev. 41, 587-640.

Harcourt, A.H., Harvey, P.H., Larson, S.G. \& Short, R.V. (1981) Testis weight, body weight and breeding system in primates. Nature, Lond. 293, 55-57.

Harvey, P.H. \& Harcourt, A.H. (1984) Sperm competition, testis size, and breeding systems in primates. In Sperm Competition and the Evolution of Animal Mating Systems, pp. 589-600. Ed. R. L. Smith. Academic Press, New York.

Islam, A.B.M.M. \& Land, R.B. (1977) Seasonal variation in testis diameter and sperm output of rams of breeds of different prolificacy. Anim. Prod. 25, 311-317.

Kenagy, G.J. \& Trombulak, S.C. (1986) Size and function of mammalian testes in relation to body size. $J$. Mammal. 67, 1-22.
Kirkwood, J.K. (1985) The influence of size on the biology of the dog. J. small Anim. Pract. 26, 97-110.

Kleiman, D.G. (1977) Monogamy in mammals. $Q$. Rev. Biol. 52, 39-69.

Parker, G.A. (1984) Sperm competition and the evolution of animal mating strategies. In Sperm Competition and the Evoluton of Animal Mating Systems, pp. 1-60. Ed. R. L. Smith. Academic Press, New York.

Seim, E. \& Saether, B-E. (1983) On rethinking allometry: which regression model to use? J. theor. Biol. 104, 161-168.

Setchell, B.P. (1978) The Mammalian Testis. Paul Elek, London.

Short, R.V. (1984) Testis size, ovulation rate and breast cancer. In One Medicine, pp. 32-44, Eds O. A. Ryder \& M. L. Byrd. Springer Verlag, Berlin.

Sokal, R.R. \& Rohlf, F.J. (1981). Biometry, 2nd edn. W.H. Freeman, San Francisco.

Wildt, D.E., Baas, E.J., Chakraborty, P.K., Wolfle, T.L. \& Stewart, A.P. (1982) Influence of inbreeding on reproductive performance, ejaculate quality and testicular volume in the dog. Theriogenology 17, 445-452.

Woolley, D.M. (1971) Selection for the length of the spermatozoa midpiece in the mouse. Genet. Res., Camb. 16, 261-275.

Woolley, D.M. \& Beatty, R.A. (1967) Inheritance of midpiece length in mouse spermatozoa. Nature, Lond. 215, 94-95.

Received 16 June 1987 